\title{
Perspective of Village Government Capacity within Village Development in Jember District
}

\author{
Dr. Selfi B. Helpiastuti, S.Sos., M.Si \\ The program of Science of State Administration \\ Faculty of Social Sciences and Political Science \\ Jember University, Indonesia \\ Moh Hasan Sabilil Maula, S.AP \\ The program of Science of State Administration \\ Faculty of Social Sciences and Political Science \\ Jember University, Indonesia \\ M Hadi Makmur, S.Sos., M.AP \\ The program of Science of State Administration \\ Faculty of Social Sciences and Political Science \\ Jember University, Indonesia
}

\begin{abstract}
The implementation of village development requires the capacity of the village government in the form of: regulatory capacity, extraction capacity, distributive capacity, responsive capacity and network capacity. Village capacity will help village governments to implement village infrastructure development in accordance with village development implementation guidelines. Type of research used in this research is descriptive type research with qualitative approach. Informants in this research are village head, village secretary, village treasurer, head of Village councils, head of hamlet, village facilitator, and community figure who know related to village development implementation activity. The result of the research shows the regulation capacity in the form village regulations of Village budget, village regulations of village government work plan, and village head's decision on implementation team. Extraction capacity is the extraction of human assets by the absorption of $\mathbf{4 0}$ original workers of the village, and the extraction of social assets in the form of community participation. Distributive capacity of the implementation authority of development there is a problem of basic tasks and functions and for the distribution of development is in accordance with the needs of the community. Responsive capacity is a verbal response by the village government over community complaints. The network capacity is in the form of cooperation between the village government and the Public Works Department, and the provider of goods and services, but the cooperation is only limited to administrative documents.
\end{abstract}

Keywords: Villages Government Capacity, Village Development

\section{INTRODUCE}

This research discusses the capacity of village government in the implementation of village development in Wringinagung Village. Preliminary observations illustrate that the implementation of development in Wringinagung village is implemented in accordance with the village income and expenditure budget, said so because the location of village development in 2016 in accordance with the area of village development in the village income and expenditure budget. However, The village income and expenditure budget Wringinagung 2016 
is different from the work plan of village government in 2016. Normally Village government work plan is a guideline for the preparation of The village income and expenditure budget, in article 81 of Law non 06 year 2014, mentioned if village development implemented in accordance with Village government work plan.

Based on the data obtained, the distribution of financial assets of Wringinagung Village is more allocated to the field of administration of village government. As for village development only 28.69\%. In addition, the form of Wringinagung Village development in the form of village infrastructure development alone. According to Law No. 06 of 2014, article 80, paragraph 4, program priorities for activities and village development needs are formulated according to the needs of the villagers in the form of quality improvement and access to basic services, development and maintenance of infrastructure, the development of productive agricultural economy and public peace.

Other problems such as the realization of the implementation of Wringinagung Village infrastructure development have not been fully realized at the end of the implementation period, December, 2016. There is unfinished development agenda, development agendas in the implementation stage and development agendas completed. The unfinished development agenda in the form of pure page installation of paving stone. Development of infrastructure Wringinagung Village management is the implementation team of activities, if referring to the nameplate in each development site, but, overall implementation of village infrastructure development is managed by the village secretary. This is the result of the lack of coordination in the management of implementation team, as evidenced by the presence of members who do not know their status as members of implementation team.

Another interesting thing in Wringinagung Village is human assets, there are 14,665 people, and has a relatively high level of education. This human asset if it can be extracted properly by the village government will have an impact on the implementation of village infrastructure development. Therefore the researchers will describe how the capacity of village government in the implementation of village development in Wringinagung Village Jember District.

\section{Village Government Capacity}

\section{LITERATURE REVIEW}

According Rozaki (2005: 225) there are several forms of capacity that need to be developed village: a. Regulatory capacity is the ability of village government to manage village life and its contents with regulation; b. Extraction capacity is the ability to collect, mobilize and optimize village assets. The village assets include: physical assets, natural assets, human assets, social assets, financial assets, and political assets; c. Distributive capacity is the ability of the village government to share village resources in a balanced and equitable way according to the needs of the community; d. Responsive capacity is the ability to be sensitive or responsive to the aspirations or needs of the community; e. Network capacity is the ability of the village government to establish cooperation with outside parties.

\section{Implementation of Village Development}

Based on Regulations of the minister of the interior no 114 of 2014 the implementation of development consists of two stages: the preparation stage and implementation phase. The preparatory phase begins with the determination of the executor of the activity, then the determination of the work plan, the socialization of activities, the provision of activities, the preparation of administrative documents, and the procurement of labor and the procurement of goods or materials. 
While the implementation stage is: work meeting of activity implementation, inspection of village infrastructure activity, change of implementation of the activity, complaint management and problem solving, preparation of activity implementation report, village meeting in the framework of implementation of village development, and preservation and utilization result of village development activity.

\section{RESEARCH METHODS}

Based on the problems and research objectives that have been described. Type of research used is descriptive qualitative research type. In order to obtain data and research information, used several techniques of data collection are: interviews, observation, and documentation. Then to validate the research data, researchers used triangulation. Determination of informant in this research using purposive technique. There were 16 informants, consisting of village heads, village officials. Head of village of Agency empowerment, implementation team members, village counselors and community leaders.

The analytical method used is an interactive analysis model created by Miles and Huberman, as follows: data collection, data reduction, data presentation, and conclusions.

\section{RESULTS AND DISCUSSION}

\section{A. Capacity of Village Government Regulation in Implementation of Development}

Analysis of regulatory capacity in the form of an analysis of regulations related to the implementation of development. The regulation is in the form of village regulations on Village government work plan, village regulations concerning The village income and expenditure budget, village head's decree on changes in development implementation, village head's decree on determination of implementation team, village head's decree on work plan, and village regulation on accountability of realization of The village income and expenditure budget implementation. The five regulations above are to support the implementation of village development, both in the preparation stage and implementation phase.

\section{1) The foundation of village development regulation in the form of the Village Government Work Program and Village Budget Rules}

Secondary data and primary data indicate if the regulatory basis for the implementation of development in Wringinagung Village is Village government work plan. The village income and expenditure budget. Both are regulations that must exist before the village administration implements the development of village infrastructure. It is said that Village regulations Village government work plan is a village planning document, while village infrastructure development is a form of implementation of the plan. Therefore, in the implementation of development must be adjusted with Village government work plan. The process of implementing the first phase of Village government work plan village infrastructure development has been enacted, then the second stage of drafting the The village income and expenditure budget, after the draft The village income and expenditure budget is approved and enacted. So the village development can be directly implemented.

However, in Wringinagung village there is an incompatibility between Village government work plan and The village income and expenditure budget, whereas both documents constitute one unity of regulation that must be in accordance with one another. But this is said not a problem by the village government, because it does not affect the implementation of village development activities. It is said if Village government work plan is only a form of priority scale. As for the priority is determined in The village income and expenditure budget. 
At this stage the government regulatory capacity, already underway, is marked by the enactment of these two Village Rules. It's just that between Village regulations Village government work plan and Village regulations The village income and expenditure budget there are mismatches. Whereas Village government work plan is a guideline for the preparation of The village income and expenditure budget. So it can be said if the foundation of the regulation of the implementation of development has not run according to existing guidelines.

\section{2) Regulation in the form of village head's decree on changes in the implementation of activities}

In Wringinagung Village there is no change in the implementation of activities, this is reflected from the results of documentation and interviews, the results of documentary studies show that each activity in accordance with the The village income and expenditure budget. As for the results of the interview mentions if the change is not implemented by the village government because the process is complicated and will hinder the implementation of other development activities. Because the village head's decree on changes in the implementation of activities was not made by the village government.

\section{3) Decree of the village head on the determination of the implementer of the activity}

Results of secondary data and primary data describes if the determination of the implementation of Wringinagung Village development is determined every year. The determination is tailored to the instructions of the local government, and endorsed by the village head's decree which is the regulation for the implementation of the development for one year. The determination of the executor of the activity is to carry out all village development activities. In addition to implementing the activities, the determination of the implementing activities is a regulatory requirement from the local government for material reporting at the end of the year.

In the Decree of the implementing team of Wringinagung Village. The head of the village acts as the person in charge, the head of Community empowerment institutions as chairman, member and head of the hamlet as a member. But there is a problem in the implementation structure of the 2016 activity, in the form of miscommunication between the village government and the members of the implementation team, this is reflected in the statement of two implementation team members, stating that they do not feel involved in the organizing of implementation team. This is because the determination mechanism does not go through the deliberation process.

The village head's decree on the implementation team is a formality, it is said so because the village head's decree on implementation team is based on the guidelines of the district or city government. As for the appointment of members of implementation team conducted without the knowledge of the parties concerned.

\section{4) The decision of the village leadership on the preparation of work plan}

The results of interviews and documentation studies illustrate if the format of village government work plans in the implementation of development is not arranged into one unit, but separately. In the documentation study it was found that the format was a cost budget plan, the implementation time plan and the location plan. The cost budget plan in Wringinagung Village is prepared by the public works department, the goal is that the village budget development budget plan can be appropriate to the needs, because if the village is composed it is feared that there will be incompatibility because the village does not have analysts. 
The timeline for the implementation of development is contained in the agreement between the village government and implementation team, while for 90 days, and described in detail in the cooperation agreement between the implementation team and the suppliers. As for the planned location of development planned in accordance with the aspirations of the community by taking into account the benefits and needs of society. These locations are listed in The village income and expenditure budget.

The preparation of the work plan of the Wringinagung Village Government if adjusted to the concept of preparation of the work plan is not appropriate. Because the work plan in the implementation of development is prepared in a work plan format that contains, description of activities, cost, time of implementation, location, target group, labor, and the list of implementing activities. The work plan format is then determined by the decision of the village head, while in Wringinagung village there is no document of the village chief's decision on the work plan. It can be said that the regulation at the stage of preparation of the work plan has not been implemented by the government of Wringinagung Village.

\section{5) Village regulations on the accountability report of the realization of The village income and expenditure budget implementation}

The results of secondary data and primary data describes if the format of the implementation report is still in the form of accountability report and not yet a Village regulations on the accountability of realization of The village income and expenditure budget implementation. The funds used for the implementation of infrastructure development in the form of village funds, and the allocation of village funds. So the form of reporting is accountability report. The composer is the village treasurer who also acts as treasurer of implementation team. Accountability report was conducted for two stages, the first accountability report was conducted as a requirement for the disbursement of the second fund, while the second accountability report was reported as a form of accountability of 100 percent implementation in the field of development implementation.

Accountability report of Wringinagung village contains the reporting of the development stage of 40 percent and 100 percent stage. It also attached some documents in it. If we adjust to the guidelines of the implementation of development, the preparation begins with the report of the executor of activities related to the development of the implementing activities. Then the report was prepared by the village head, covering the realization of costs, photos of village infrastructure activities conditions $0.40,80,100$ percent, photos showing people at work, photos of community participation and other documents. But from the primary data describe the reporting process in Wringinagung Village is not initiated by the report of activity development by the executor of the activity, but directly through the village treasurer, because he felt as the person in charge of preparing the report as treasurer of implementation team, said so because between implementation team and implementation team is one unity.

A description of the five indicators of the village government's regulatory capacity in the implementation of the above development illustrates that if there are any regulations in the implementation of the regulation, there is no problem in implementing the activities, because the village government of Wringinagung does not change the implementation of the activities.

\section{B. Capacity of Village Government Extraction in the Implementation of Village Development}

This analysis is based on the results of documentary studies, interviews, and observations related to the ability of village governments to collect, mobilize, and maximize village assets in the implementation of development, while village assets related to infrastructure development 
are assets of human resources and natural resources and assets social. Therefore the researchers conducted an analysis to determine the level of extraction ability of village government Wringinagung in the implementation of village development.

\section{1) The extraction capacity of village human resources assets in the implementation of village development}

Extraction of human resource assets in the labor force for the implementation of village infrastructure development. Workforce in the implementation of village infrastructure development can be done through two models, first through the contractor and the second form of self-managed. Self-management is the procurement of labor that require village government to run its role in the field of human resource assets extraction capacity. It is said that because self-managed is defined as the procurement of own workforce by the village government or implementation team.

The village government of Wringinagung used two models to obtain the labor of village infrastructure development implementers. First through the contractor because the infrastructure development of Wringinagung Village is a type of development above Rp50,000,000 to Rp200,000,000. In addition, there are five development points of village infrastructure that require heavy construction. The labor absorbed through the contractor as many as 72 people.

The second stage through self-managed, because at three points the construction of village infrastructure is a light construction building. So for the procurement of manpower can be through the optimization of village human resources assets. Manpower absorbed through selfmanaged as many as 40 people. However, if referring to the hubs, the three types of lightweight construction buildings must be through the provider of goods and services, because it is a type of building above Rp50.000.000 to Rp200.000.000. Therefore, the village government cooperates with corporate partners in the field of administration documents of procurement of goods and services to avoid regulation from the district government, which is irrelevant to the directive of Regulations of the minister of the interior 114 year 2014.

\section{2) Analysis of village natural resource extraction capacity in the implementation of Wringinagung Village infrastructure development 2016}

Goods or materials in the implementation of village infrastructure development prioritize the existing natural resources of the village first, then if the village resources can't be extracted into materials or materials for the construction of village infrastructure, then it can be contracted. The results of observation, documentation, and interviews describe if in the village Wringinagung no natural resources that can be used as materials or materials for the construction of village infrastructure. Wringinagung Village Resources capable of providing goods or materials not through its natural resources, but through human resources. Because in Wringinagung Village there are five building stores that can provide materials or materials for the implementation of village infrastructure development.

Researchers display data of goods or materials that can be provided and can't be provided by the village resources in appendix P. But the problem is the provider of goods or materials in the village can't meet the requirements as a provider of goods or materials. For that reason, the Wringinagung Village Government has not been able to collect and optimize resources to support the implementation of village development in 2016. Another factor that makes the village government of Wringinagung not procure goods and services through five building stores in the village. Because at the hub no 15 of 2015 said if for development above Rp50.000.000 up to Rp200.000.000 must use one suppliers who are able to provide goods or 
materials needed. Therefore the village government in cooperation with the corporate partners in the field of administrative documents procurement of goods and services. However, for the owner itself is done by the government of Wringinagung Village, for the provider of goods or material can't be informed by informants, because it is a village secret.

\section{3) Capacity of extraction of social assets in the form of socialization of activities to mobilize the community to participate in the implementation of village infrastructure development}

The results of observations and interviews illustrate if the socialization of development activities in the village wringinagung 2016, conducted through the media information boards and socialization in each hamlet conducted by the head of the hamlet. Board information related to development activities placed in front of the village office, and for socialization by the head of the hamlet, the mechanism of gathering RT, RW dibalai hamlet. Then the head of the hamlet to socialize the development activities that are located each compiled. The purpose of this socialization so that people can know the activities of village development, and expected to respond to the efforts of village governments to mobilize the village social assets to participate in the implementation of development.

The socialization of activities in Wringinagung village still looks modest compared to the guidelines for the implementation of village development, the optimal form of socialization begins with the village meeting, then the village meeting, village information system, and village website if any. The socialization materials are the work plans of the village government and the budget of village income and expenditure. Although fairly simple, the socialization of activities undertaken by the village government, was able to mobilize community participation in the form of community participation in the implementation of development.

This participation is a form of community response to what has been socialized by the village government. The interview results illustrate if the form of community participation is not in the form of participation of personnel or material participation, but the form of participation in the form of participating in monitoring the implementation of development, and provide financial participation in the form of snacks and drinks. This is done in turn by the villagers during the development process takes place.

\section{Analysis of Distributive Capacity of Village Governments in the Implementation of Village Development}

Analysis of distributive capacity in the implementation of development is mapped into two parts, namely distribution distribution, distribution of authority. The results of interviews with some informants illustrate if both distributions need to be considered in the implementation of village development.

\section{1) Distribution of development in each hamlet}

Results of secondary data and interviews illustrate if the proportion of development distribution in each hamlet is not the same. Because it takes into account the real needs of each hamlet and the benefit for the community, and considers the population and the area of the hamlet. This uneven distribution then led to fewer conflicts in the hamlet community that received fewer development rations, but after getting an explanation from the village head, the community could be conditioned. The turmoil in the community occurred in Pondok Jeruk Barat hamlet.

If viewed from the standpoint of Has benefits, the decision of the distribution of development sites can be said to be in accordance with the needs of society. This is evidenced by the 
expression of some communities in the development location, the average society felt the benefits of village development in 2016. So it can be said if the distribution of development in Wringinagung Village is in accordance with the standard that has been determined together through village consultation forum.

\section{2) Distribution of authority}

There is a problem in the distribution of authority, namely the unclear task and function of the village government, this is evidenced by the results of observations that indicate if the executor of development is implementation team, whereas if referring from the results of interviews and triangulation of sources illustrates if the implementation of village development in 2016 implemented by the secretary village. So it can be said if there is delegation of authority to the village secretary. Whereas the authority to carry out the implementation of development is entirely the duty of the implementation team.

Unclear tasks and functions of this subsequently lead to a bad image for the village government. The underlying reason for this problematic is because implementation team members are incapable of performing their duties. So the village secretary will attend all forms of village development implementation in 2016.

\section{Responsive Capacity of Wringinagung Village Government in the implementation of village development}

This responsive capacity analysis is related to the stages of development implementation. Be it the preparation stage and the implementation phase. Responsiveness is defined as a form of village government's sensitivity to community aspirations as well as community complaints. Form of sensitivity in the implementation of village infrastructure development in the form, Management and problem solving.

Management and problem solving in the implementation of village infrastructure development is intended to solve problems that occur in the field. The form of reporting can be through a suggestion box or verbally. The results of the observation illustrates if the problem of the location of the development there is only prepared Waluh hamlet. In the form of asphalt damage due to heavy loads. Interviews indicate that if the community has reported to the village government, but due to budget constraints, the village government can't make improvements.

The results of interviews and observations and documentation illustrate if there is no effort from the village government to solve the problem. Other than that the village government also does not communicate with the parties causing the problem. It is said if there is no effort because of the results of documentary studies the researchers did not find the news deliberation of the problem solving. Interview results also illustrate if a new problem solving will be implemented if there is more budget.

Another problem in the implementation of village development in 2016 is the transparency of development implementation and the lack of clarity of the main duties and functions between the head of implementation team and the village secretary. Both of these problems are often complained of by the community, but the response from the village government tends to be low. Even can be said not responded by the village government, the form of response made by the village government even in the form of self-defense. That is to say if the head of implementation team in 2016 does not have the capacity to implement development. So that can be drawn red thread if the village government response to public complaints in the field of 
development implementation is limited to verbal actions only. It is proved by the absence of the village government's efforts to solve the problems that people complain.

\section{E. Village Government Network Capacity in Implementation of Village Development}

Forms of village government cooperation with third parties, in the form of inspection of village infrastructure built in 2016, the village government cooperates with the district government, the format of the district provides briefing to the village head related to the implementation guidelines and Technical guidance development in 2016. Other cooperation established by the government Village Wringinagung in the implementation of village development, ie with the providers of goods and services. As well as, with the public works agency to help check the implementation of village infrastructure development.

\section{1) Implementer briefing activities}

The results of interviews and documentation studies illustrate if the debriefing of the executor of activities carried out by the district government, the materials are socialized in the form of technical manuals and implementation manuals. Participants invited were village heads, village secretaries, and Agency empowerment of village leaders. The result of the briefing is then placed in the village office, so that village instruments and organizations can understand the material.

The truth of the debriefing of the implementers of this activity by the district is evidenced by the technical guidance material and the existing implementation manual at the village office. If related to the concept of debriefing published by the Regulations of the minister of the interior , the lack of this stage is only a debriefing participant, mentioned if the participant debriefing invited only the village head, village secretary, and chairman of BPD while the guidance of the parties who need to follow the debriefing include the executor of the activity, the procurement committee And services, community empowerment cadres, and community empowerment agencies.

\section{2) Cooperation with providers of goods or services}

The results of the documentation illustrates if the village government cooperates with corporate patners as the provider of goods or services, but the cooperation is only limited to the fulfillment of administrative documents only. As stated by several informants at the time of the research. This is done in order to fulfill Article 12 of Regent regulation of Jember no 15 of 2015 , it is said that if the procurement of goods or services with value above Rp50,000,000 up to Rp200.000.000 is implemented under the terms, implementation team buys goods or services to one provider of goods or services.

\section{3) Cooperation with public works office to investigate village infrastructure}

The results of the interviews illustrate that if the village government cooperates with the public works office to inspect the development of village infrastructure by 2016, the intention of holding this inspection is for accountability materials for second period fund disbursement. The Public Works Party conducts examinations at 40 percent and 100 percent. The concept of village government in conducting inspection of village infrastructure prioritizes the utilization of human resources in the village, and if from the village community can't afford the village government can establish cooperation with third parties.

Normally the examination is conducted in three stages, the first stage of the assessment and examination of 40 percent, the second stage of assessment and inspection of 80 percent of the overall target, the third examination and assessment and inspection of 100 percent of the overall target, which will then be reported to the village head. So it can be understood if the 
capacity of the village government network is still merely a cooperation with the public works agency.

\section{CONCLUSION}

Based on the results of research on Perspective of Village Government Capacity within Village Development in Jember District, it can be concluded the following things.

A. The regulation capacity in the implementation of development in the form of Village government work plan village regulation, village regulation The village income and expenditure budget, and decree of village head about determination of implementation team. While Village regulations accounting for the realization of the implementation of The village income and expenditure budget is still not completed, the decree of the village head about the work plan for the implementation of development is not made, and the decree of the village head about the change of implementation of the activity is not held. Because in the Village Wringinagung in 2016 did not make changes to the implementation of activities. But in the regulation that has been enacted there are still problems.

B. The Extraction capacity of village government in the implementation of the development of the absorption of 40 people original labor village. The village government also succeeded in mobilizing social assets, in the form of community participation in the implementation of development. As for the natural assets are not in extraction by the village government, because the natural assets of Wringinagung Village can't be used as materials or materials for the construction of village infrastructure.

C. The distribution capacity of the village government in the implementation of development in the form of distribution of village infrastructure development whose benefits can be felt by the community evenly. As for the distribution of authority there is still unclear task and principal functions of the village infrastructure development actors.

D. The responsive capacity of village government in the implementation of development is verbal response, without any action to prevent or solve the problem of village infrastructure development.

E. The network capacity in the implementation of development in the form of cooperation of village government with public works office, coordinate with regency or city government. While cooperation with the providers of goods and services is only in the form of administrative documents only.

\section{BIBLIOGRAPHY}

Miles, Matthew dan Huberman, A. Michael. 2007. Qualitative Data Analysis: The Source Book About New Methods. Jakarta: UI Press

Moh. Hasan S.M. et al. 2017. The Government Villages Capacity on the Construction Villages of the Villages Wringinagung Subdistrict Jombang District Jember. Jember University.

Regulation of the Minister of Home Affairs of the Republic of Indonesia Number 114 Year 2014. Village

Development Guidelines. 31 December 2014. State Gazette of the Republic of Indonesia Year 2014 Number 2094. Jakarta.

Jember Regent Regulation No. 15 of 2015. Procedures for Procurement of Goods Or Services in the Village. 02 February 2015. Jember

Village Regulation Wringinagung Number 6 Year 2015. Work Plan Village Government Year 2016. December 10, 2015. Wringinagung.

Village Regulation Wringinagung Number 2 Year 2016. Budget Revenue and Expenditure Wringinagung Village Year 2016. 2 August 2016. Wringinagung.

Rozaki et al. 2005. Prakasa Decentralization and Village Autonomy. Yogyakarta: IRE Press 
Helpiastuti, S. B., Maula, M. H. S., \& Makmur, M. H. (2017). Perspective of Village Government Capacity within Village Development in Jember District. Advances in Social Sciences Research Journal, 4(15) 172-182.

Decree of Wringinagung Village Head No. 05 Year 2016. Village Management Activity Team Wringinagung Village Infrastructure Development And Community Empowerment Activities 2016. 24 July 2016. Wringinagung

Law of the Republic of Indonesia Number 6 Year 2014. Village. 15 January 2014. State Institution of the Republic of Indonesia Year 2014 Number 7. Jakarta.

Widjaja, H. 2003. Village Autonomy. Jakarta: PT Raja Grafindo Persada. 